\title{
Study and Implementation of the Fuzzy Mamdani and Sugeno Methods in Decision Making on Selection of Outstanding Students at the South Aceh Polytechnic
}

\author{
Amsar Yunan a,1, Muhammad Ali ${ }^{\mathrm{b}}$ \\ a,b, Department of Computer Engineering, Polytechnic of South Aceh, Tapaktuan Indonesia \\ lamsar@poltas.ac.id
}

\begin{abstract}
The selection of students who excel academically is a measure of education quality in an educational institution. In the implementation of education, student achievement becomes a measure of academic success at the institution. Achievement results from hard work by following the rules given by a particular person or institution with specific criteria and conditions to determine if someone is eligible to be chosen as an award recipient. This research uses the Mamdani Fuzzy method or Fuzzy inference system. Sugeno Fuzzy designed this decision-making system to develop the decision results from the rules compiled using Matlab software for testing. The South Aceh Polytechnic holds special student elections every year. The selection of students with achievements that are carried out every year only focuses on the GPA value in academic achievement without looking at the determining factors which are more precise. In the research that will be conducted, the selection must meet the eligibility criteria as a student who gets an award or as an outstanding student at the South Aceh Polytechnic involving variables in the Cumulative Achievement Index, Final Project value, Extracurricular, and Attendance. Research is expected to be a tool in the selection process for candidate participants who complete the selection of outstanding students at the South Aceh Polytechnic. So, relevant departments in universities can determine the eligibility of prospective students as award recipients as students with the best achievement scores by considering the relevant determining factors. The expected output using the Mamdani and Sugeno fuzzy method can become an intellectual property system. This system can be selected as a guideline by the South Aceh Polytechnic academic for determining outstanding students. The research results show that the level of truth is $86.82 \%$ for the Mamdani method, while the implementation of Sugeno Fuzzy logic is obtained a level of reality of $71.88 \%$.
\end{abstract}

Keywords:

Decision Making,

Achievements,

Fuzzy,

Mamdani,

Sugeno.

\section{Introduction}

The selection of students who excel academically is a measure of education quality in an educational institution [1]. Achievement results from hard work by following the rules given by a person or institution with specific criteria to determine if someone deserves to be selected as an award recipient. If it is related to higher education, the achievement is when a student can excel in college and other academic skills, which are the determining variables for the student being selected as the student with the best academic achievement [2]. In a study conducted by Laras Purwati Ayuningtias et al. To predict the number of new students in the following year by looking at the number of new students in the previous year, this study uses three fuzzy methods, namely Tsukamoto, Sugeno, and Mamdani fuzzy. The research that has been done obtained the error rate of each way, where the Mamdani Fuzzy method error is $19.76 \%$, Tsukamoto Fuzzy is $39.03 \%$, and Fuzzy Sugeno is $86.41 \%$ [3]. Dorteus Lodewyik Rahakbauw also conducted this research using the 
Fuzzy Sugeno method. His research on determining the amount produced by a bakery based on the production of the amount of demand and inventory data helped determine the factory's amount of bread. The results obtained a truth level of $86.92165 \%$ [4].

Furthermore, research conducted by Eka Mahargiyak et al. Regarding the application of the Sugeno method of Fuzzy Logic for Weather Forecasting Decision Support Systems, this study directs to be able to do weather forecasts by implementing the Sugeno Fuzzy process and can also see and calculate the level of accuracy of the data from the research results. The results show that manual data verification tests and system verification in the excellent category, where manual data verification was $76 \%$, and system data verification tests were $74 \%$ [5].

Based on other researchers' research related to decision-making systems, the decisions taken must meet the eligibility criteria as outstanding students for the study to be conducted. Therefore, the South Aceh Polytechnic College, a three-year diploma that produces graduates with skills and skills, is held annually to select outstanding students for those who have completed semester VI (six) and only those who can complete studies for 3 (three) years. The selection of exceptional students is based on the GPA score without looking at other more precise variables, such as nonacademic student activities or even collecting several assessment items and determining the average number of the determined items so that each assessment's accuracy is less than optimal. In this study, the selection of high-achieving students must involve variables in the form of Grade Point Average, Final Project Value, Extracurricular, and Attendance. The results of this study serve as guidelines or aids in decision making in determining outstanding students. This decision-making system is designed using tools in the form of a Graphic User Interface (GUI) in Matlab.

\section{Theoretical Background}

2.1 Fuzzy Logic or Fuzzy Inference System

Fuzzy logic is one of the scientific fields of technology related to the formation of soft computing to sets as input variables will be designed with rules so that a decision can be taken. As illustrated in Figure 1 below:

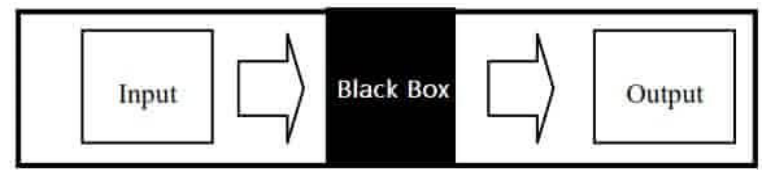

Figure 1. Mapping the input-output process in fuzzy [6]

It uses fuzzy logic to combine a broad set of fundamental indicators and then calculates a numerical value of sustainability for many hands to draw a logical conclusion [7]. As mentioned earlier, Fuzzy is a component of soft computing formation. In terms of this, Fuzzy logic can also be interpreted as a vague or vague decision. A value in this fuzzy can be either broad or false simultaneously because, in the Fuzzy term, the degree of membership has an interval of 0 (zero) to 1 (one). The person who first introduced fuzzy theories in scientific studies was Prof. Lotfi Zadeh in 1965. Prof. Lotfi Zadeh, who is currently a reference for many researchers, said that set theory plays an essential role in determining the membership function or a term known in fuzzy, namely the degree of membership [8]. The Mamdani Fuzzy method is a fuzzy inference system because the technique is a combination of each fuzzy rule. The degree of membership is calculated to be defuzzified to get the relevant results in a system [9].

This fuzzy relationship is based on addition and multiplication obtained from vague rules. This solution is offered by fuzzy logic in making decisions from a compiled law, also known as the fuzzy arithmetic model. This Fuzzy relationship turns out to be a solution to the conclusion system so that theoretical and practical results are obtained [10].

\subsection{Membership Function}

The membership function is a curve that shows the mapping of data input points into its membership value or the degree of membership. This degree of membership has a value range from 0 to $1[8]$. There are several membership functions, such as triangle curve representation and trapezoidal curve representation. 


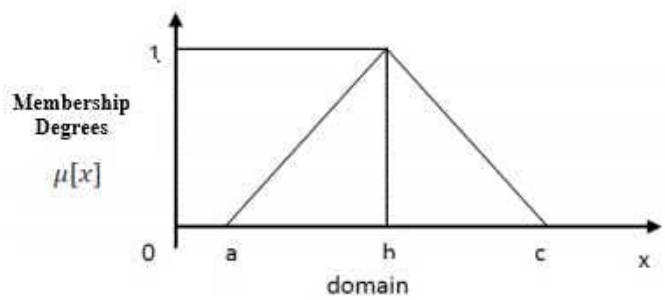

$$
\mu[x]=\left\{\begin{array}{cc}
0 ; & x \leq a \text { or } x \geq c \\
\frac{x-a}{b-a} & a \leq x \leq b \\
\frac{b-x}{c-b} & x \geq 60
\end{array}\right.
$$

Figure 2. Triangle Curve

Furthermore, the implantation of the trapezoid curve is a combination of the representation of the triangle curve, only if in this curve, some member values are 1.

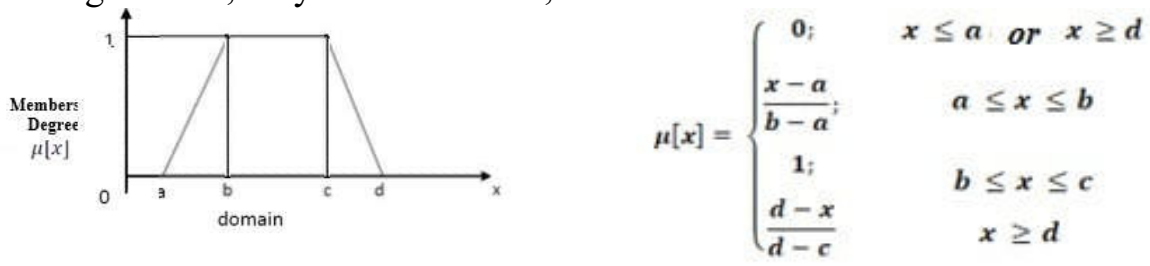

Figure 3. Trapezium curve

\subsection{Fuzzy Mamdani}

Mamdani Fuzzy logic is a scientific theory known as Max-Min. The first time to introduce this theory was Ebrahim Mamdani in 1975. The fuzzy Mandani started from creating fuzzy sets, designing rules that are often known as rules or other terms. Application of implication functions that become benchmarks for decision making, the composition of management, and defuzzification [11].

In the Mamdani fuzzy method, there are several steps as follows:

1. Determine the fuzzy set used

First, determine a fuzzy set and decide what variables are included in the input and output variables.

2. Forming the implication function

The implication function uses the AND operator or the OR operator. If using AND, then the minimum role is taken. On the other hand, if OR, the maximum function is taken, then it is connected with the THEN command for the decision to be taken, generally as follows [8]: $\operatorname{IF}\left(\mathrm{x}_{1}\right.$ is $\left.\mathrm{A}_{1}\right)$ AND ( $\mathrm{x}_{2}$ is $\left.\mathrm{A}_{2}\right)$ AND $\left(\mathrm{x}_{3}\right.$ is $\left.\mathrm{A}_{3}\right) \ldots$ AND ( $\mathrm{x}_{\mathrm{n}}$ is $\left.\mathrm{A}_{\mathrm{n}}\right)$ THEN $\mathrm{y}$ is $\mathrm{B}$.

3. Determine rules (the composition of rules)

The composition uses the Mamdani composition or the term MAX-MIN as well.

4. Defuzzification

Confirmation is a process of defuzzification in each set. Defuzzification is obtained from several fuzzy set variables so that it is connected to the output as the final result obtained is followed up in decision making [12].

\subsection{Fuzzy Sugeno}

Logical decision-making with the Sugeno method is related and close by drawing conclusions made with the Mamdani method. Mamdani's difference is only in the output where the system is not a Fuzzy set an equation or constant, a technique introduced by Sugeno Kang in 1986 [13]. This Sugeno in its membership function is in Singleton. The membership function has a membership degree of 1 at a single crisp value, while in other crisp matters is 0 .

There are two parts to Sugeno's fuzzy model:

1. Zero-Order Fuzzy Sugeno Model

The following formula is Sugeno's fuzzy form in general in Zero-Order, namely: IF ( $\mathrm{x} 1$ is $\mathrm{A} 1) \cdot(\mathrm{x} 2 \text { is } \mathrm{A} 2)^{\circ}(\mathrm{x} 3$ is $\mathrm{A} 3) \cdot$ - $(\mathrm{xN}$ is $\mathrm{An})$ THEN $\mathrm{z}=\mathrm{k}$

Where: Ai is the ith Fuzzy set as an antecedent (reason), and $\mathrm{k}$ is a constant (emphatic) as a consequence (conclusion).

2. Fuzzy Sugeno Order-1 Model

$\operatorname{IF}(x 1 \text { is a } 1)^{\circ}(x 2 \text { is A2 })^{\circ} \ldots{ }^{\circ}(x n$ is An $)$ THEN $z=p 1 * x 1+\ldots+p n * x n+q$, 
Where: $\mathrm{Ai}$ is the ith fuzzy set as an antecedent (reason), ${ }^{\circ}$ is the fuzzy operator (AND or $\mathrm{OR})$, pi is the ith constant, and q is also continuous in consequence.

\subsection{Decision support system}

A decision support system can be a system that provides data modeling to help make a semistructured decision. That someone will never know the pattern of decision making on decisions received from certain parties cannot be traced with certainty how to produce the decisions given [14]. In this study using Matlab software for testing, the illustration of test design as in Figure 4 below:

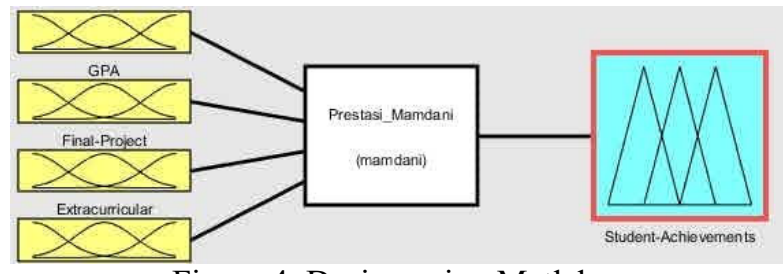

Figure 4. Design using Matlab

In Figure 4 above, the flow of decision making using the fuzzy method is to collect input variables then compile rules to get the final decision. The compilation of the number of rules uses the permutation formula. The permutation is a system of compiling a set of objects arranged in an order that is different from one another without any repetitive arrangements because the permutation sequence is crucial [15].

$$
n P r=n^{r}
$$

Where $\mathrm{n}$ is the number of objects that can be selected, and $\mathrm{r}$ is the number of items specified.

\subsection{Mean Percentage Error (MPE)}

After the testing process is carried out, calculating the correctness of the tests carried out is then carried out, using either the Mamdani fuzzy logic method or the Sugeno Fuzzy logic method. At the calculation stage, the truth value uses the mean percent error value known as the Mean Percentage Error (MPE) [16].

$$
M P E=\frac{\sum_{t=1}^{n} \frac{\left(Y_{t}-\hat{Y}_{t}\right)}{Y_{t}} \times 100 \%}{n}
$$

In this equation, $t=1$ to $n$ indicates the amount of data, $Y_{t}$ is the original data, $\hat{Y}_{t}$ is the $I$ observation's predicted value, and $\mathrm{n}$ is the amount of data.

\section{Method}

This research was designed by following the Mamdani and Sugeno fuzzification systems. The work system in this study is as follows:

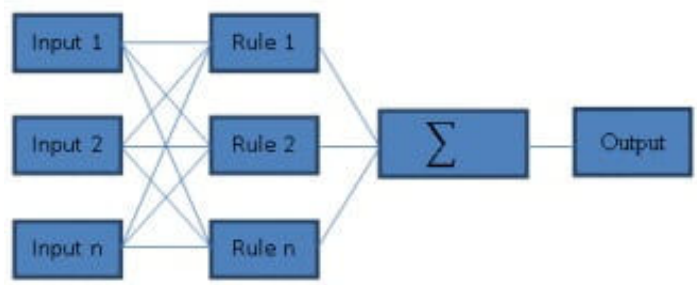

Figure 5. Research Concept Scheme

From the conceptual scheme of this research, the decision-making system is based on input variables. The rules for the testing process are carried out using the fuzzy Mamdani and Sugeno logic methods. The final result is a decision in the form of outstanding students.

The data collection method is by taking data from students in semester VI (six) who have completed three years of study for testing. Data for graduates over three years will not be processed to be included in this decision-making system. Table 1 is the sample data used. 
Table 1. Testing data

\begin{tabular}{|c|c|c|c|c|c|}
\hline \multirow[b]{2}{*}{ No } & \multirow[b]{2}{*}{$\begin{array}{c}\text { Name of } \\
\text { the student }\end{array}$} & \multicolumn{4}{|c|}{ Variable } \\
\hline & & $\begin{array}{l}\text { IPK/ } \\
\text { GPA }\end{array}$ & $\begin{array}{c}\text { Final } \\
\text { project }\end{array}$ & $\begin{array}{l}\text { Extracurri } \\
\text { cular }\end{array}$ & Attendance \\
\hline 1 & Student01 & 3.38 & 86.75 & 73 & 95.34 \\
\hline 2 & Student 02 & 3.25 & 79.58 & 195 & 92.85 \\
\hline 3 & Student03 & 3.19 & 79.30 & 79 & 90.03 \\
\hline 4 & Student04 & 3.71 & 87.04 & 156 & 95.60 \\
\hline 5 & Student05 & 3.30 & 82.00 & 63 & 93.80 \\
\hline 6 & Student06 & 3.16 & 85.02 & 72 & 90.00 \\
\hline 7 & Student07 & 3.15 & 82.01 & 86 & 86.65 \\
\hline 8 & Student08 & 2.61 & 74.56 & 67 & 65.40 \\
\hline 9 & Student09 & 3.35 & 86.07 & 192 & 93.65 \\
\hline 10 & Student10 & 3.57 & 85.81 & 126 & 97.60 \\
\hline 11 & Student11 & 3.01 & 75.00 & 71 & 80.00 \\
\hline 12 & Student12 & 3.39 & 88.16 & 82 & 90.10 \\
\hline 13 & Student13 & 3.09 & 85.80 & 65 & 80.40 \\
\hline 14 & Student14 & 2.61 & 79.10 & 75 & 60.80 \\
\hline 15 & Student15 & 3.26 & 85.40 & 122 & 84.90 \\
\hline 16 & Student16 & 2.95 & 82.16 & 67 & 70.35 \\
\hline 17 & Student17 & 3.23 & 84.00 & 83 & 90.20 \\
\hline 18 & Student18 & 2.84 & 80.07 & 63 & 76.65 \\
\hline 19 & Student19 & 2.85 & 80.70 & 66 & 68.93 \\
\hline 20 & Student 20 & 2.86 & 82.36 & 86 & 78.70 \\
\hline 21 & Student21 & 3.00 & 82.02 & 90 & 80.70 \\
\hline 22 & Student 22 & 2.89 & 86.25 & 50 & 75.00 \\
\hline 23 & Student 23 & 3.25 & 87.06 & 70 & 90.80 \\
\hline 24 & Student24 & 3.27 & 86.56 & 68 & 83.30 \\
\hline 25 & Student 25 & 3.38 & 87.69 & 144 & 90.20 \\
\hline 26 & Student 26 & 3.42 & 89.96 & 85 & 95.52 \\
\hline 27 & Student27 & 3.21 & 85.50 & 72 & 90.70 \\
\hline 28 & Student28 & 3.25 & 80.00 & 98 & 89.65 \\
\hline 29 & Student29 & 3.49 & 86.45 & 59 & 94.70 \\
\hline 30 & Student 30 & 2.97 & 83.97 & 102 & 80.00 \\
\hline 31 & Student31 & 2.94 & 86.73 & 49 & 64.90 \\
\hline 32 & Student32 & 3.35 & 85.48 & 84 & 95.30 \\
\hline 33 & Student33 & 3.15 & 87.48 & 60 & 85.34 \\
\hline 34 & Student34 & 3.10 & 85.90 & 74 & 80.21 \\
\hline 35 & Student35 & 2.93 & 86.88 & 85 & 78.50 \\
\hline 36 & Student36 & 3.08 & 85.30 & 85 & 87.00 \\
\hline 37 & Student37 & 3.33 & 89.00 & 42 & 93.45 \\
\hline 38 & Student38 & 3.34 & 90.30 & 114 & 93.33 \\
\hline 39 & Student39 & 2.95 & 86.92 & 64 & 70.76 \\
\hline 40 & Student 40 & 3.07 & 86.10 & 40 & 82.70 \\
\hline
\end{tabular}

\section{Result And Discussion}

\section{A. Set Formation and Implication Function}

The formation of this fuzzy set includes four variable parts, including the GPA, Final Project, Extracurricular, and Attendance variables. Each input variable has a linguistic function consisting of three parts: low, medium, and high. In comparison, the output variable has four linguistic functions, namely less, enough, reasonable, and best.

Table 2. Formation of fuzzy sets and their domain

\begin{tabular}{|c|c|c|c|}
\hline \multirow{2}{*}{$\begin{array}{c}\text { Input } \\
\text { Variable }\end{array}$} & \multicolumn{2}{|c|}{ fuzzy set } & \multirow{2}{*}{$\begin{array}{c}\text { The semester of } \\
\text { conversation }\end{array}$} \\
\hline & Type & Domain & \\
\hline \multirow{3}{*}{ IPK } & Low & $0-3$ & \multirow{3}{*}{$0-4$} \\
\hline & Medium & $2.5-3.5$ & \\
\hline & High & $3-4$ & \\
\hline \multirow{3}{*}{ Final Project } & Low & $0-70$ & \multirow{3}{*}{$0-100$} \\
\hline & Medium & $60-90$ & \\
\hline & High & $80-100$ & \\
\hline \multirow{3}{*}{$\begin{array}{l}\text { Extracurricula } \\
\mathrm{r}\end{array}$} & Low & $0-100$ & \multirow{3}{*}{$0-300$} \\
\hline & Medium & $50-200$ & \\
\hline & High & $150-300$ & \\
\hline \multirow{2}{*}{ Attendance } & Low & $0-60$ & \multirow{2}{*}{$0-100$} \\
\hline & Medium & $50-90$ & \\
\hline
\end{tabular}




\begin{tabular}{cccc}
\hline \multirow{2}{*}{$\begin{array}{c}\text { Input } \\
\text { Variable }\end{array}$} & \multicolumn{2}{c}{ fuzzv set } & The semester of \\
& Type & Domain & conversation \\
\cline { 2 - 3 } & High & $80-100$ & \\
\hline \multirow{3}{*}{ Output } & Less & $0-30$ & \\
& Enough & $20-60$ & $0-100$ \\
\cline { 2 - 3 } & Good & $50-90$ & 0 \\
\cline { 2 - 3 } & Best & $80-100$ & \\
\hline
\end{tabular}

\section{B. Application function Implication of input}

The application of the implication function of each input value of each variable can be seen in Figure 6 to Figure 10.

1. Variable IPK / Grade Point Average GPA

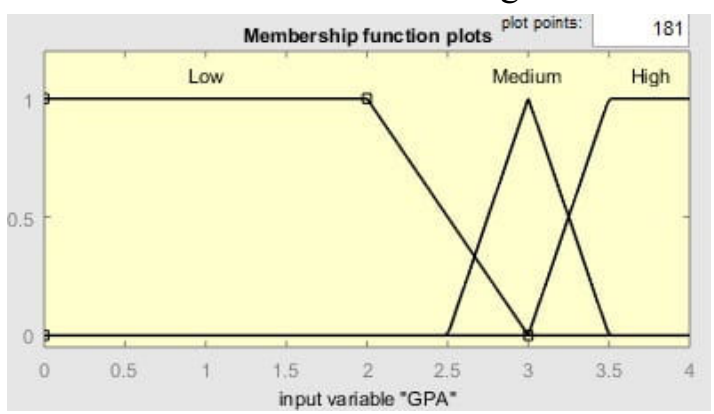

Figure 6. Application of GPA implication function

2. Variable Final Project

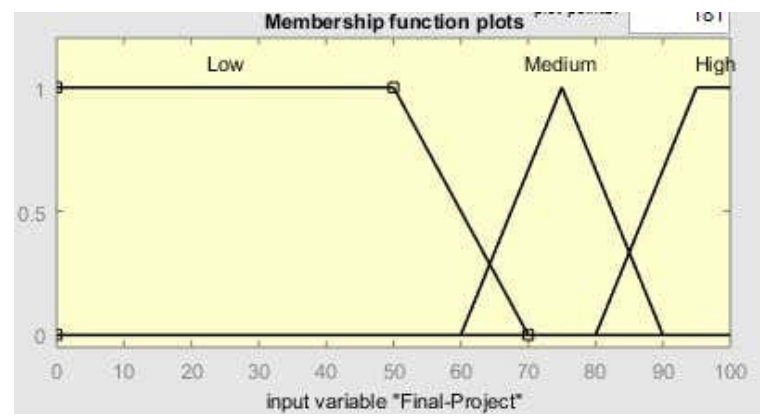

Figure 7. Application of Final Project implication function

3. Variable Extracurricular

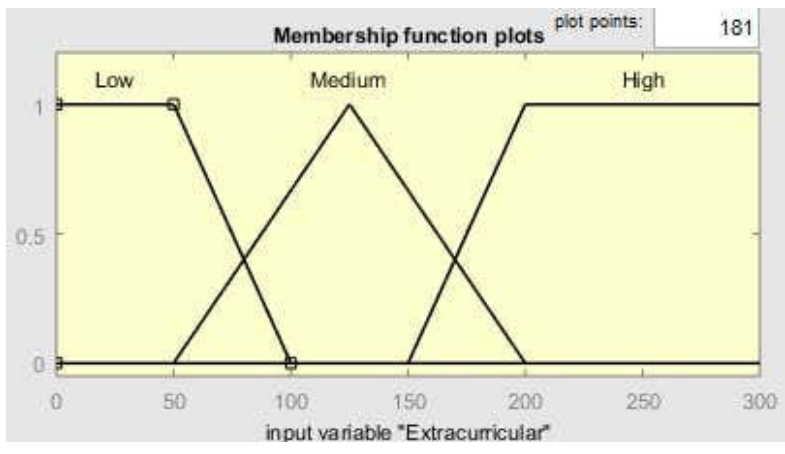

Figure 8. Application of Extracurricular implication function
Membership function

$$
\begin{aligned}
& \mu_{\text {Low }[x]}=\left\{\begin{array}{cc}
1 ; & x \leq 2 \\
\frac{3-x}{3-2} & 2 \leq x \leq 3 \\
0 ; & x \geq 3
\end{array}\right. \\
& \mu_{\text {Medium }}[x]=\left\{\begin{array}{cc}
\frac{x-2}{3-2} & 2 \leq x \leq 3 \\
1 ; & x=3 \\
\frac{3.5-x}{3.5-3} & 3 \leq x \leq 3.5
\end{array}\right. \\
& \mu_{\text {High }}[x]=\left\{\begin{array}{cc}
\frac{x-3}{3.5-3} & 3 \leq x \leq 3.5 \\
1 ; & x \geq 3.5
\end{array}\right.
\end{aligned}
$$

Membership function

$$
\begin{aligned}
& \mu_{\text {Low }}[x]=\left\{\begin{array}{cc}
1 ; & x \leq 50 \\
\frac{70-x}{70-50} & 50 \leq x \leq 70 \\
0 ; & x \geq 70
\end{array}\right. \\
& \mu_{\text {Medium }}[x]=\left\{\begin{array}{cc}
\frac{x-60}{75-60} & 60 \leq x \leq 75 \\
1: & x=75 \\
\frac{90-x}{90-75} & 75 \leq x \leq 90
\end{array}\right. \\
& \mu_{\text {High }}[x]=\left\{\begin{array}{cc}
\frac{x-80}{95-80} & 80 \leq x \leq 95 \\
1 & x \geq 95
\end{array}\right.
\end{aligned}
$$

Membership function

$$
\begin{aligned}
\mu_{\text {Low }}[x] & =\left\{\begin{array}{cc}
1 ; & x \leq 50 \\
\frac{100-x}{100-50} & 50 \leq x \leq 100 \\
0 ; & x \geq 100
\end{array}\right. \\
\mu_{\text {Medium }}[x] & =\left\{\begin{array}{cc}
\frac{x-50}{125-50} & 50 \leq x \leq 125 \\
1 ; & x=125 \\
\frac{200-x}{200-125} & 125 \leq x \leq 200
\end{array}\right. \\
\mu_{\text {High }}[x] & =\left\{\begin{array}{cc}
\frac{x-150}{200-150} & 150 \leq x \leq 200 \\
1 ; & x \geq 200
\end{array}\right.
\end{aligned}
$$


4. Variable Attendance

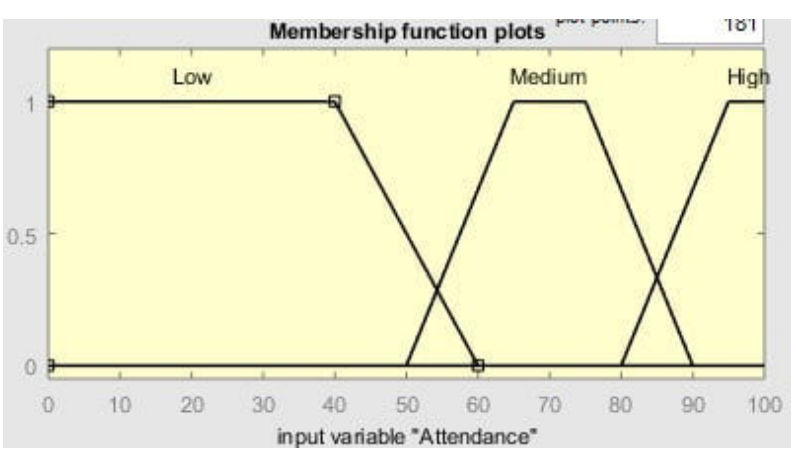

Membership function

$$
\begin{aligned}
& \mu_{\text {Low }}[x]=\left\{\begin{array}{cc}
1 ; & x \leq 40 \\
\frac{60-x}{60-40} & 40 \leq x \leq 60 \\
0 ; & x \geq 60
\end{array}\right. \\
& \mu_{\text {Medium }}[x]=\left\{\begin{array}{cc}
0 & 50 \leq x \text { atau } x \geq 9 \\
\frac{x-50}{65-50} & 50 \leq x \leq 65 \\
1 ; & 65 \leq x \leq 75 \\
\frac{90-x}{90-75} & x \geq 90
\end{array}\right. \\
& \mu_{\text {High }}[x]=\left\{\begin{array}{cc}
\frac{x-80}{95-80} & 80 \leq x \leq 95 \\
1 ; & x \geq 95
\end{array}\right.
\end{aligned}
$$

Figure 9. Application of Attendance implication function

The percentage value range of output from research with the Mamdani and Sugeno fuzzy methods is given the recommendation size is $0-100 \%$ to get the value as a participant of outstanding students. The Mamdani method can be seen in Figure 10 below:

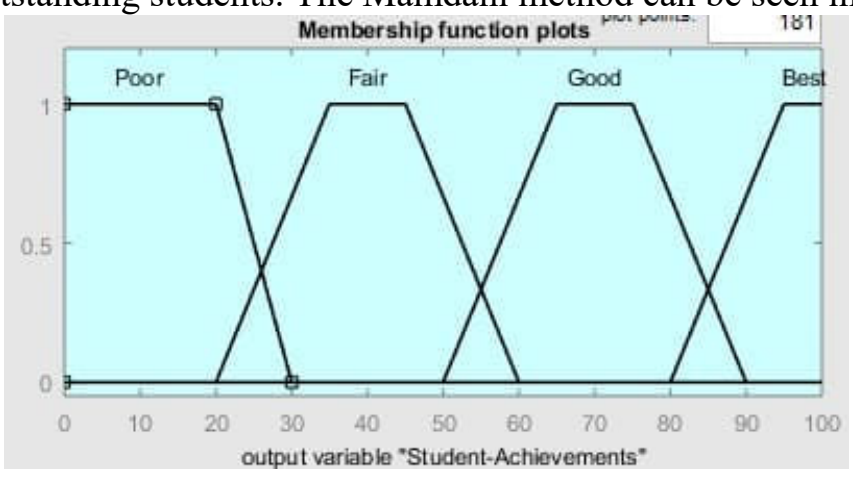

$$
\begin{aligned}
& \text { Membership function } \\
& \mu_{\text {poor }}[x]=\left\{\begin{array}{cc}
1: & x \leq 20 \\
\frac{30-x}{30-20} & 20 \leq x \leq 30 \\
0 ; & x \geq 30
\end{array}\right. \\
& \mu_{\text {Fair }}[x]=\left\{\begin{array}{cc}
\frac{x-20}{35-20} & 20 \leq x \text { atau } x \geq 60 \\
1: & 35 \leq x \leq 45 \\
\frac{60-x}{60-45} & x \geq 60
\end{array}\right. \\
& \mu_{\text {Good }}[x]=\left\{\begin{array}{cc}
0 & 50 x \text { atau } x \geq 90 \\
\frac{x-50}{65-50} & 50 \leq x \leq 65 \\
1: & 65 \leq x \leq 75 \\
90-x & x \geq 90
\end{array}\right. \\
& \mu_{\text {Best }}[x]=\left\{\begin{array}{cc}
\frac{x-75}{95-80} & 80 \leq x \leq 95 \\
1 ; & x \geq 95
\end{array}\right.
\end{aligned}
$$

Figure 10. Application of Output implication function

The use of Mamdani and Sugeno methods is almost the same. Only the difference is in the output process. There is no classification for each value to be issued, but in Sugeno, determining the final value uses linear and constant choices. In this test using the continuous option to see the output value by taking the lowest value at the initial output in the form of a value of 0 , the middle value between the initial and final values, namely, the category is entirely worth 40 and the Good type is worth 70 . The absolute value is taken as the highest output value in the class for the output-best worth 100. The view can be seen in Figure 11 below.

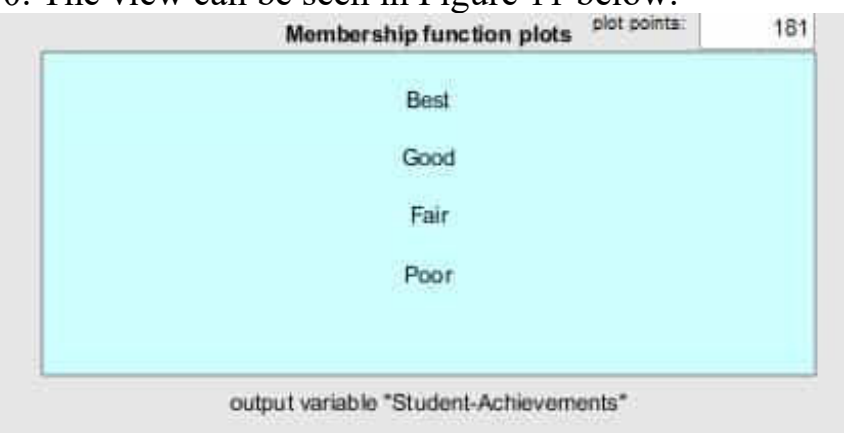

Figure 11. Sugeno fuzzy method output

\section{Fuzzy rules applied.}

In this research, two methods are used: using the Mamdani fuzzy logic method and Sugeno fuzzy logic. The fuzzy rules are formulated with the fuzzy criteria Low, Enough, Medium, High. With Variable (Variable $=1,2,3,4)$. The number of these rules of 81 is obtained from equation (2.3). The formula used in this equation is :

$$
n P r=n^{2 r}
$$

where $\mathrm{n}$ is the number of objects that can be selected, and $\mathrm{r}$ is the number of items selected. So we get the fuzzy rule total used to be 81 rules by substituting it into the equation: $n^{r}=3^{4}=81$. 
Table 3. Fuzzy rules

\begin{tabular}{cccccc}
\hline \multirow{2}{*}{$\begin{array}{c}\text { No } \\
\text { Rules }\end{array}$} & \multicolumn{4}{c}{ Fuzzy set } & Decision \\
\cline { 2 - 5 } & IPK/GPA & Final Project & Extracurricular & Attendance & (Then) \\
\hline 1 & High & High & High & High & Best \\
\hline 2 & High & High & High & Medium & Best \\
\hline 11 & High & Medium & High & Medium & Good \\
\hline 12 & High & Medium & High & Low & Good \\
\hline 24 & High & Low & Medium & Low & fair \\
\hline 25 & High & Low & Low & High & fair \\
\hline 80 & Low & Low & Low & Medium & Poor \\
\hline 81 & Low & Low & Low & Low & Poor \\
\hline
\end{tabular}

The test results with the Graphic User Interface process with Matlab using both Mamdani and Sugeno methods can be seen in Figure 12 and Figure 13 below.

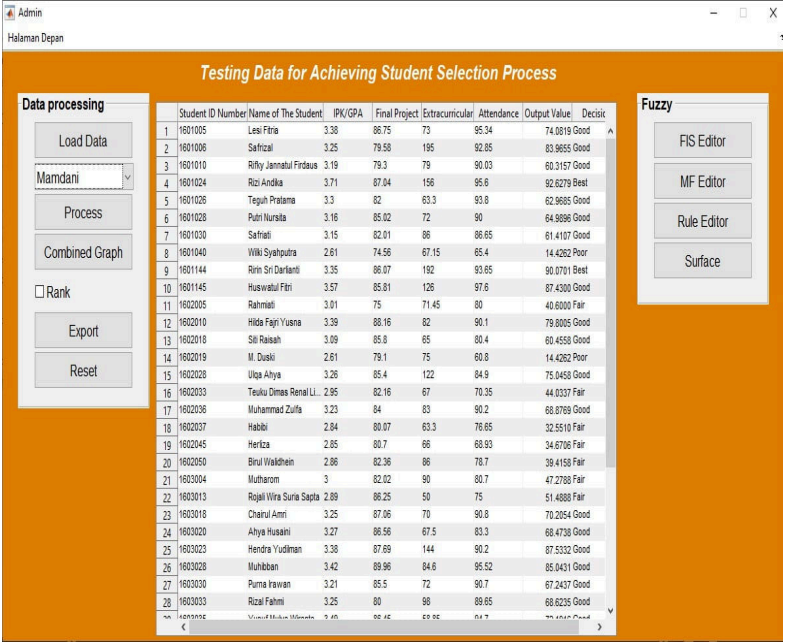

Figure 12. Testing the data of the Mamdani method

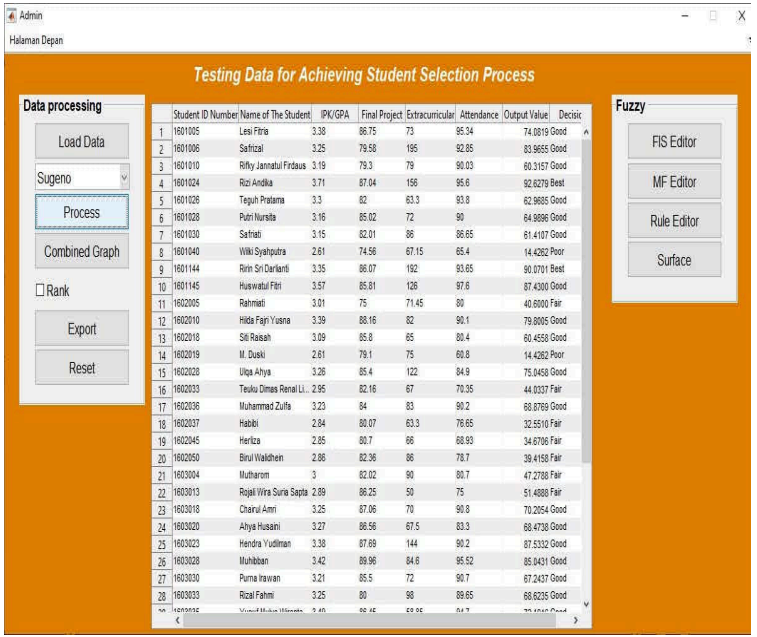

Figure 13. Testing the data of the Sugeno method

The test graph is shown in Figure 14 and Figure 15 below.

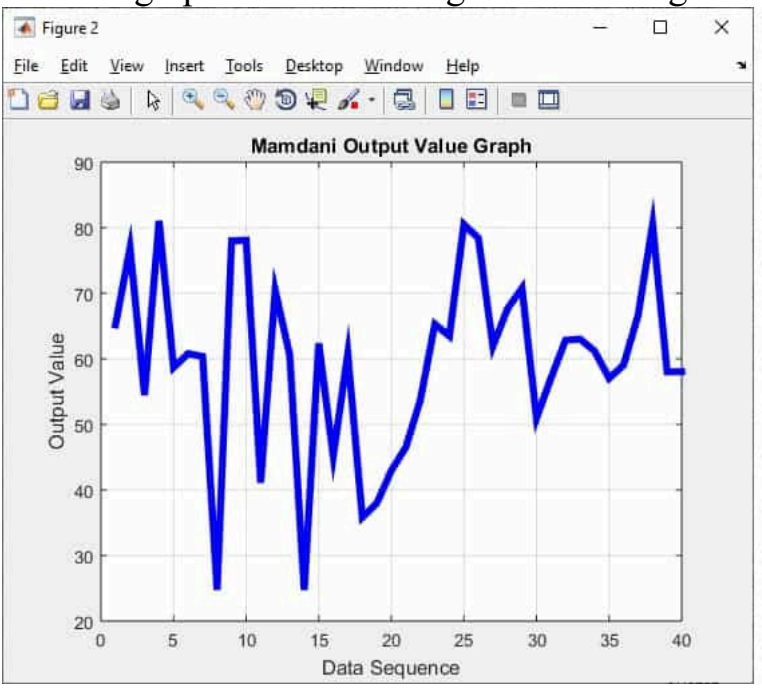

Figure 14. Graph of Mamdani data testing

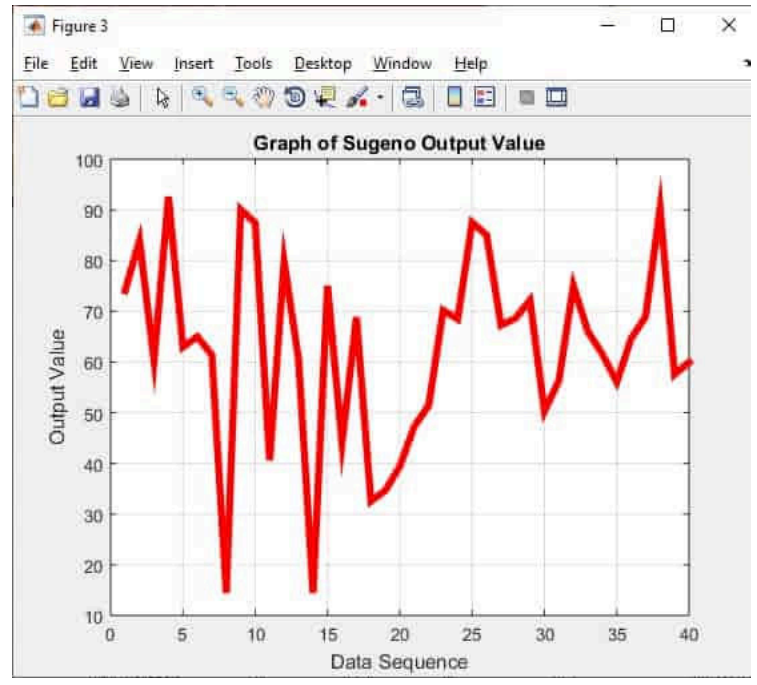

Figure 15. Graph of Sugeno data testing

The combination of the two graphs of the methods used, both the Sugeno method and the Mamdani test method, can be seen in Figure 16. 


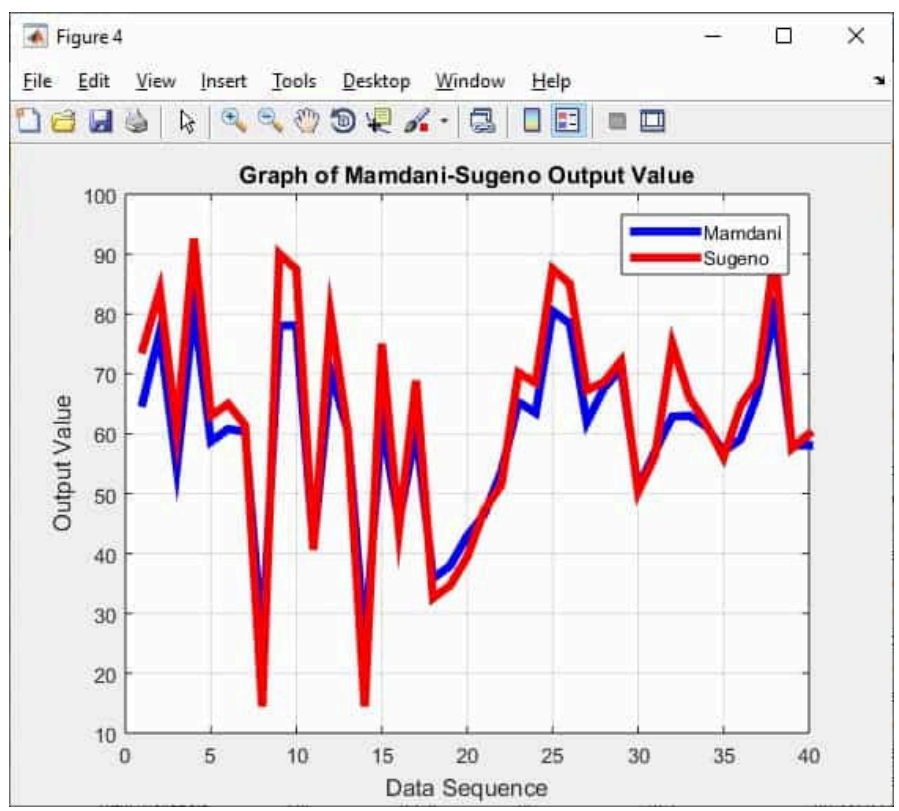

Figure 16. Graph of the Mamdani and Sugeno method student data testing

\section{The rank of test output results}

After all the data has been inputted, then sorting the data or ranking the data from the largest to the smallest output is carried out. The ranking results between the Mamdani and Sugeno methods have differences in order. This is because the system in the final decision has differences between methods. The ranking order of the Mamdani method can be shown in Figure 17 below.

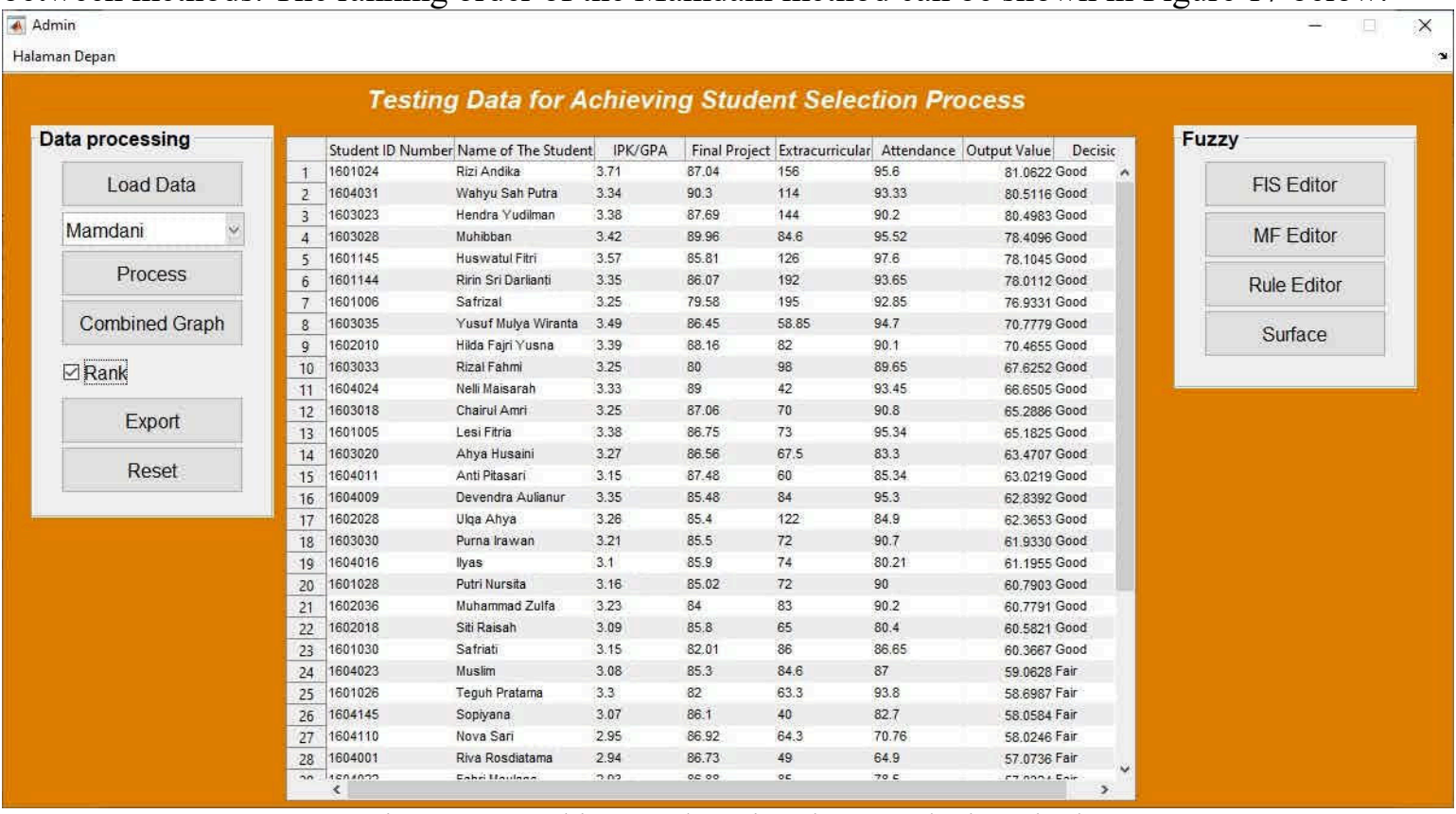

Figure 17. Ranking results using the Mamdani method

After sorting the output value from the values is shifted to the lowest, then an Export process is carried out for data storage. The steps for ranking and exporting data can also be done using the Sugeno method. From the tests, it found that the students with the highest score with the Mandani method are students on behalf of Student 04 with an output value of 81.06 in the "Good" category. While using the Sugeno method, the name of the student who was declared students also obtained "Best" on the same name, namely Student 04, with an output value of 92.63. The test results using the Sugeno method can be seen in Figure 18 below. 


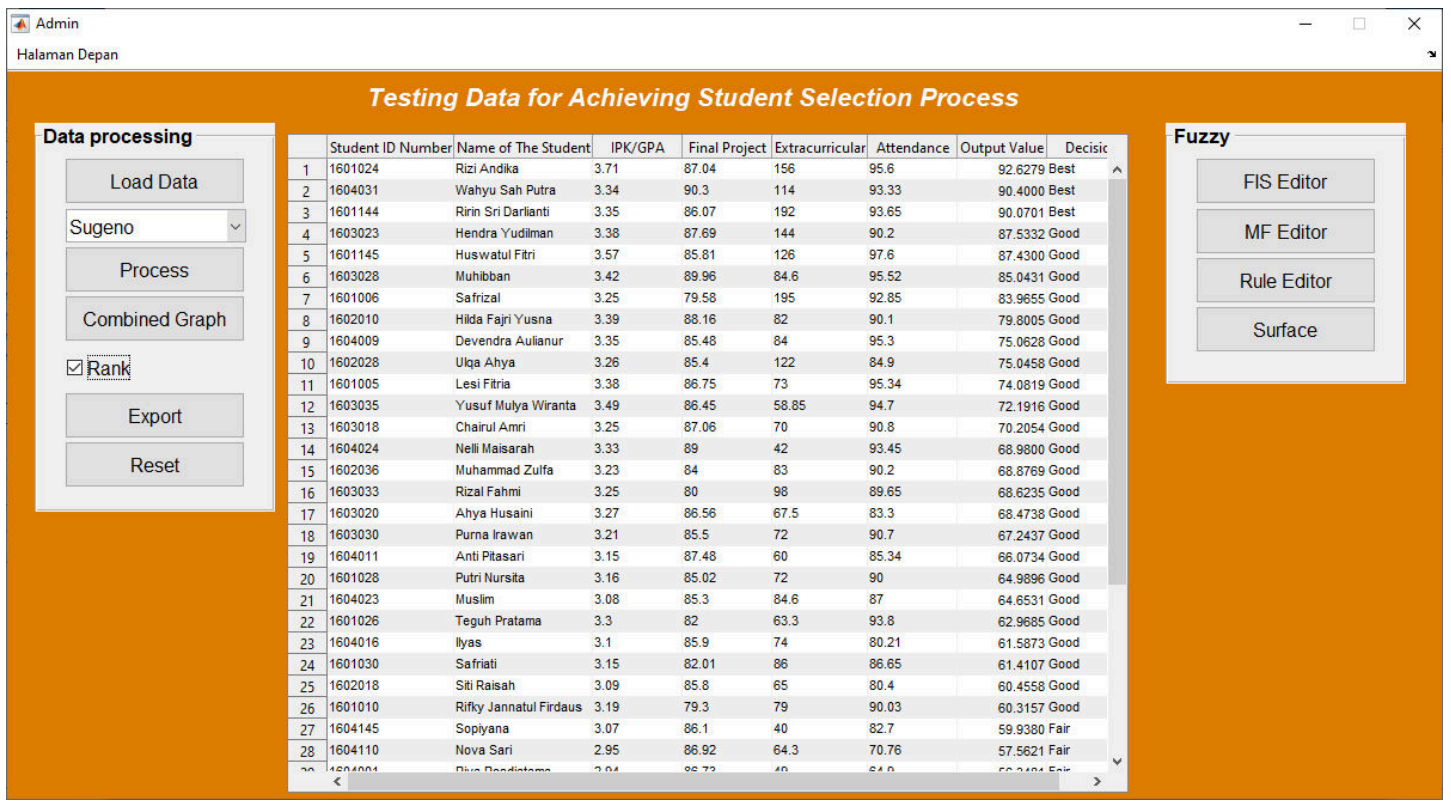

Figure 18. Ranking results using the Sugeno method

\section{E. Analysis of the Mamdani and Sugeno fuzzy methods}

The results of the comparison between testing with the Mamdani and Sugeno fuzzy logic methods obtained a distinct difference in numbers, both testing with the Mamdani method or Sugeno method, both of these methods have been tested which produce new data, so users can use which way to use in the data testing process. In determining outstanding students at the South Aceh Polytechnic. The following tables and graphs illustrate the comparison results obtained after testing. For more details, see the following Tables and Graphs.

Table 4. Comparison of Test Results

\begin{tabular}{llcccccc}
\hline & & \multicolumn{5}{c}{ Testing Method } \\
\cline { 3 - 8 } No & $\begin{array}{c}\text { Name of } \\
\text { the student }\end{array}$ & \multicolumn{3}{c}{ Mamdani } & \multicolumn{3}{c}{ Sugeno } \\
\cline { 3 - 8 } & & Output & Decision & Rank & Output & Decision & Rank. \\
\hline 1 & Student01 & 65.18 & Fair & 13 & 74.08 & Good & 11 \\
\hline 2 & Student02 & 76.93 & Good & 7 & 83.97 & Best & 7 \\
\hline 3 & Student03 & 54.46 & Fair & 30 & 60.32 & Fair & 26 \\
\hline 4 & Student04 & 81.06 & Best & 1 & 92.63 & Best & 1 \\
\hline 5 & Student05 & 58.70 & Fair & 25 & 62.91 & Fair & 22 \\
\hline 6 & Student06 & 60.79 & Fair & 20 & 64.99 & Fair & 20 \\
\hline 7 & Student07 & 60.37 & Fair & 23 & 61.41 & Fair & 24 \\
\hline 8 & Student08 & 24.76 & Poor & 39 & 14.43 & Poor & 39 \\
\hline 9 & Student09 & 78.01 & Good & 6 & 90.07 & Best & 3 \\
\hline 10 & Student10 & 78.10 & Good & 5 & 87.43 & Best & 5 \\
\hline 11 & Student11 & 41.10 & Poor & 36 & 40.60 & Poor & 35 \\
\hline 12 & Student12 & 70.47 & Good & 9 & 79.80 & Good & 8 \\
\hline 13 & Student13 & 60.58 & Fair & 22 & 60.46 & Fair & 25 \\
\hline 14 & Student14 & 24.76 & Poor & 40 & 14.43 & Poor & 40 \\
\hline 15 & Student15 & 62.37 & Fair & 17 & 75.05 & Good & 10 \\
\hline 16 & Student16 & 45.18 & Fair & 34 & 44.03 & Poor & 34 \\
\hline 17 & Student17 & 60.78 & Fair & 21 & 68.88 & Fair & 15 \\
\hline 18 & Student18 & 35.82 & Poor & 38 & 32.55 & Poor & 38 \\
\hline 19 & Student19 & 37.97 & Poor & 37 & 34.67 & Poor & 37 \\
\hline 20 & Student20 & 42.97 & Poor & 35 & 39.42 & Poor & 36 \\
\hline 21 & Student21 & 46.52 & Fair & 33 & 47.28 & Fair & 33 \\
\hline 22 & Student22 & 53.73 & Fair & 31 & 51.49 & Fair & 31 \\
\hline 23 & Student23 & 65.29 & Fair & 12 & 70.21 & Good & 13 \\
\hline 24 & Student24 & 63.59 & Fair & 14 & 68.58 & Fair & 17 \\
\hline & & & & & & & \\
\cline { 3 - 7 } & & & & & & \\
\hline
\end{tabular}




\begin{tabular}{llcccccc}
\hline & & \multicolumn{5}{c}{ Testing Method } \\
\cline { 3 - 8 } No & $\begin{array}{c}\text { Name of } \\
\text { the student }\end{array}$ & \multicolumn{3}{c}{ Mamdani } & \multicolumn{3}{c}{ Sugeno } \\
\cline { 3 - 8 } & & Output & Decision & Rank & Output & Decision & Rank. \\
\hline Be & Student25 & 80.50 & Best & 3 & 87.53 & Best & 4 \\
\hline 26 & Student26 & 78.60 & Good & 4 & 85.27 & Best & 6 \\
\hline 27 & Student27 & 61.93 & Fair & 18 & 67.24 & Fair & 18 \\
\hline 28 & Student28 & 67.63 & Fair & 10 & 68.62 & Fair & 16 \\
\hline 29 & Student29 & 70.81 & Good & 8 & 72.24 & Good & 12 \\
\hline 30 & Student30 & 50.94 & Fair & 32 & 50.30 & Fair & 32 \\
\hline 31 & Student31 & 57.07 & Fair & 28 & 56.35 & Fair & 29 \\
\hline 32 & Student32 & 62.84 & Fair & 16 & 75.06 & Good & 9 \\
\hline 33 & Student33 & 63.02 & Fair & 15 & 66.07 & Fair & 19 \\
\hline 34 & Student34 & 61.20 & Fair & 19 & 61.59 & Fair & 23 \\
\hline 35 & Student35 & 57.03 & Fair & 29 & 56.08 & Fair & 30 \\
\hline 36 & Student36 & 59.27 & Fair & 24 & 64.75 & Fair & 21 \\
\hline 37 & Student37 & 66.65 & Fair & 11 & 68.98 & Fair & 14 \\
\hline 38 & Student38 & 80.51 & Best & 2 & 90.40 & Best & 2 \\
\hline 39 & Student39 & 58.02 & Fair & 27 & 57.56 & Fair & 28 \\
\hline 40 & Student40 & 58.06 & Fair & 26 & 59.94 & Fair & 27 \\
\hline & & & & & & &
\end{tabular}

From the test results, it can be seen that the comparison of the two methods used, the error rate process of these two methods, is obtained from the calculation of the average results of each input variable. This intermediate result is used as the initial test value before the testing process is carried out using the Mamdani and Sugeno fuzzy logic methods. Each input variable with the test results of the two ways in making student achievers decisions, the error rate amount can use equation (4).

$$
M P E=\frac{\sum_{i=1}^{n} \frac{\left(Y_{t}-\hat{Y}_{t}\right)}{Y_{t}} \times 100 \%}{n}
$$

Using the MPE formula, the truth value can be solved using the mean percent error value / also known as the Mean Percentage Error (MPE), as in Table 5 below:

Table 5. Calculation results of the Mean Percentage Error level

\begin{tabular}{llccccccc}
\hline \multirow{2}{*}{ No } & \multirow{2}{*}{$\begin{array}{c}\text { Name of } \\
\text { the student }\end{array}$} & \multirow{2}{*}{$\begin{array}{c}\text { Initial } \\
\text { value }\end{array}$} & \multicolumn{3}{c}{ Mamdani } & \multicolumn{3}{c}{ Sugeno } \\
\cline { 5 - 9 } & & Output & Error & MPE & Output & Error & MPE \\
\hline 1 & Student01 & 64.62 & 65.18 & 0.59 & 0.91 & 74.08 & 9.46 & 12.78 \\
\hline 2 & Student02 & 92.67 & 76.93 & 15.74 & 16.98 & 83.97 & 8.70 & 10.36 \\
\hline 3 & Student03 & 62.88 & 54.46 & 8.42 & 13.39 & 60.32 & 2.56 & 4.24 \\
\hline 4 & Student04 & 85.59 & 81.06 & 4.53 & 5.29 & 92.63 & 7.04 & 7.60 \\
\hline 5 & Student05 & 60.60 & 58.70 & 1.90 & 3.14 & 62.91 & 2.31 & 3.66 \\
\hline 6 & Student06 & 62.55 & 60.79 & 1.75 & 2.81 & 64.99 & 2.44 & 3.76 \\
\hline 7 & Student07 & 64.45 & 60.37 & 4.09 & 6.34 & 61.41 & 3.04 & 4.95 \\
\hline 8 & Student08 & 52.43 & 24.76 & 27.67 & 52.78 & 14.43 & 38.00 & 263.41 \\
\hline 9 & Student09 & 93.77 & 78.01 & 15.76 & 16.80 & 90.07 & 3.70 & 4.11 \\
\hline 10 & Student10 & 78.25 & 78.10 & 0.14 & 0.18 & 87.43 & 9.19 & 10.51 \\
\hline 11 & Student11 & 57.37 & 41.10 & 16.26 & 28.35 & 40.60 & 16.77 & 41.31 \\
\hline 12 & Student12 & 65.91 & 70.47 & 4.55 & 6.90 & 79.80 & 13.89 & 17.40 \\
\hline 13 & Student13 & 58.57 & 60.58 & 2.01 & 3.43 & 60.46 & 1.88 & 3.12 \\
\hline 14 & Student14 & 54.38 & 24.76 & 29.62 & 54.47 & 14.43 & 39.95 & 276.93 \\
\hline 15 & Student15 & 73.89 & 62.37 & 11.52 & 15.60 & 75.05 & 1.16 & 1.54 \\
\hline 16 & Student16 & 55.62 & 45.18 & 10.43 & 18.76 & 44.03 & 11.58 & 26.30 \\
\hline 17 & Student17 & 65.11 & 60.78 & 4.33 & 6.65 & 68.88 & 3.77 & 5.47 \\
\hline 18 & Student18 & 55.72 & 35.82 & 19.89 & 35.70 & 32.55 & 23.16 & 71.15 \\
\hline 19 & Student19 & 54.62 & 37.97 & 16.65 & 30.49 & 34.67 & 19.95 & 57.54 \\
\hline 20 & Student20 & 62.48 & 42.97 & 19.51 & 31.23 & 39.42 & 23.06 & 58.50 \\
\hline 21 & Student21 & 63.93 & 46.52 & 17.41 & 27.24 & 47.28 & 16.65 & 35.22 \\
\hline 22 & Student22 & 53.54 & 53.73 & 0.19 & 0.35 & 51.49 & 2.05 & 3.98 \\
\hline & & & & & & & & \\
\hline
\end{tabular}




\begin{tabular}{|c|c|c|c|c|c|c|c|c|}
\hline \multirow{2}{*}{ No } & \multirow{2}{*}{$\begin{array}{c}\text { Name of } \\
\text { the student }\end{array}$} & \multirow{2}{*}{$\begin{array}{l}\text { Initial } \\
\text { value }\end{array}$} & \multicolumn{3}{|c|}{ Mamdani } & \multicolumn{3}{|c|}{ Sugeno } \\
\hline & & & Output & Error & MPE & Output & Error & MPE \\
\hline 23 & Student23 & 62.78 & 65.29 & 2.51 & 4.00 & 70.21 & 7.43 & 10.58 \\
\hline 24 & Student 24 & 60.16 & 63.59 & 3.43 & 5.70 & 68.58 & 8.42 & 12.28 \\
\hline 25 & Student 25 & 81.32 & 80.50 & 0.82 & 1.01 & 87.53 & 6.22 & 7.10 \\
\hline 26 & Student26 & 68.38 & 78.60 & 10.23 & 14.96 & 85.27 & 16.90 & 19.81 \\
\hline 27 & Student 27 & 62.85 & 61.93 & 0.92 & 1.46 & 67.24 & 4.39 & 6.53 \\
\hline 28 & Student 28 & 67.73 & 67.63 & 0.10 & 0.15 & 68.62 & 0.90 & 1.31 \\
\hline 29 & Student29 & 60.87 & 70.81 & 9.94 & 16.33 & 72.24 & 11.36 & 15.73 \\
\hline 30 & Student30 & 67.24 & 50.94 & 16.29 & 24.23 & 50.30 & 16.93 & 33.66 \\
\hline 31 & Student31 & 50.89 & 57.07 & 6.18 & 12.14 & 56.35 & 5.46 & 9.68 \\
\hline 32 & Student32 & 67.03 & 62.84 & 4.19 & 6.26 & 75.06 & 8.03 & 10.70 \\
\hline 33 & Student33 & 58.99 & 63.02 & 4.03 & 6.83 & 66.07 & 7.08 & 10.72 \\
\hline 34 & Student34 & 60.80 & 61.20 & 0.39 & 0.64 & 61.59 & 0.78 & 1.27 \\
\hline 35 & Student35 & 63.33 & 57.03 & 6.30 & 9.94 & 56.08 & 7.25 & 12.93 \\
\hline 36 & Student36 & 65.00 & 59.27 & 5.73 & 8.81 & 64.75 & 0.24 & 0.37 \\
\hline 37 & Student37 & 56.95 & 66.65 & 9.71 & 17.05 & 68.98 & 12.04 & 17.45 \\
\hline 38 & Student38 & 75.24 & 80.51 & 5.27 & 7.00 & 90.40 & 15.16 & 16.77 \\
\hline 39 & Student39 & 56.23 & 58.02 & 1.79 & 3.18 & 57.56 & 1.33 & 2.31 \\
\hline 40 & Student40 & 52.97 & 58.06 & 5.09 & 9.61 & 59.94 & 6.97 & 11.63 \\
\hline \multicolumn{3}{|c|}{ Total Error percentage } & \multicolumn{3}{|c|}{527.09} & \multicolumn{3}{|c|}{1124.66} \\
\hline \multicolumn{3}{|c|}{ Average Percentage of errors } & \multicolumn{3}{|c|}{13.18} & \multicolumn{3}{|c|}{28.12} \\
\hline \multicolumn{3}{|c|}{ Data correctness level } & \multicolumn{3}{|c|}{$86.82 \%$} & \multicolumn{3}{|c|}{$71.88 \%$} \\
\hline
\end{tabular}

From Table 5 above, from the calculations that have been done using the formula to find the actual value by calculating the mean percent error value or also known as the Mean Percentage Error (MPE), the average percentage error rate results from calculations using both methods. The fuzzy Mamdani logic testing method obtained a total of 527.09 divided by the amount of data, namely 40 parts. The results of this division obtained an average error rate of $13.18 \%$. While the truth level from these calculations' effects is $100 \%$ minus $13.18 \%$, then the truth level is $86.82 \%$. While the Sugeno fuzzy logic test method obtained a total of 1124.66 divided by the amount of data, namely 40 parts, this division's results got an average error rate of $28.12 \%$. while the level of truth from the effects of these calculations is $100 \%$ minus $28.12 \%$, then the truth level is $71.88 \%$

\section{Conclusion}

Based on the results of research on the study of the implementation of the decision-making process for the selection of outstanding students at the South Aceh Polytechnic using the Mamdani and Sugeno fuzzy logic method, it can be concluded that:

1. The stages in selecting outstanding students begin with determining the fuzzy set, determining the application of the implication function, compiling the rules used in the fuzzification calculation process, determining defuzzification to get a firm value of the decision results, ranking methods, and selecting a list of names that are included in the highest score as outstanding students.

2. The testing process can be presented in a Graphic User Interface (GUI) display in Matlab 2015a so that the user or admin can input data into the system that has been built for the output process.

3. A comparison of the correct level value in the study, with 40 students obtained a different level of truth. For the Fuzzy Mamdani logic method, the right level is $86.82 \%$, while the application of Fuzzy Sugeno logic gets a truth level of $71.88 \%$.

\section{References}

[1] Muna Erawati, "Prestasi Akademik Siswa Dalam Kaitannya Dengan Motivasi Akademik, Persepsi Terhadap Dukungan Akademik Dan Peran Orang Tua,” Universitas Gajah Mada, 2015.

[2] R. A. Purba, "Memprediksi Prestasi Mahasiswa Politeknik Unggul LP3M dengan Menggunakan 
Jaringan Saraf Tiruan dan Fuzzy,” Semin. Nas. Teknol. Inf. dan Multimed., pp. 1-6, 2018.

[3] M. Irfan, L. P. Ayuningtias, and J. Jumadi, "Analisa Perbandingan Logic Fuzzy Metode Tsukamoto, Sugeno, Dan Mamdani (Studi Kasus : Prediksi Jumlah Pendaftar Mahasiswa Baru),” J. Tek. Inform., vol. 10, no. 1, pp. 9-16, 2018, doi: 10.15408/jti.v10i1.6810.

[4] D. L. Rahakbauw, "Penerapan Logika Fuzzy Metode Sugeno Berdasarkan Data Persediaan Dan Jumlah Permintaan ( Studi Kasus : Pabrik Roti Sarinda Ambon ) Application of Fuzzy Logic Method Sugeno To Determine the Total Production of Bread ," vol. 9, pp. 121-134, 2015.

[5] E. Mahargia, D. Anggraeni P, R. Wandiro S, and Y. Mahzar, "Penerapan Logika Fuzzy Metode Sugeno untuk Sistem Pendukung Keputusan Prakiraan Cuaca,” Universitas Brawijaya, 2013.

[6] A. Wantoro and A. T. Priandika, "Komparasi Perhitungan Pemilihan Mahasiswa Terbaik Menggunakan Metode Statistik Klasik Dengan Logika Fuzzy (Tsukamoto Dan Mamdani," Semin. Nas. Teknol. Inf., pp. 25-32, 2017.

[7] V. D. Kouloumpis, V. S. Kouikoglou, and Y. A. Phillis, "Sustainability Assessment of Nations and Related Decision Making Using Fuzzy Logic," IEEE Syst. J., vol. 2, no. 2, pp. 224-236, 2008, DOI: 10.1109/JSYST.2008.925256.

[8] Sri Kusumadewi, Aplikasi Logika Fuzzy untuk Pendukung Keputusan2. Yogyakarta: Graha Ilmu, 2013.

[9] Ferdinandus and I. luvi I. Astutik, "Sistem pendukung keputusan untuk membantu siswa sma kelas xii dalam menentukan jurusan di perguruan tinggi dengan menggunakan logika fuzzy metode mamdani," Sist. Nas. "Inovasi dalam Desain dan Teknol., pp. 158-168, 2015.

[10] M. Stetnicha, B. De Baets, and L. Noskova, “Arithmetic fuzzy models," IEEE Trans. Fuzzy Syst., vol. 18, no. 6, pp. 1058-1069, 2010, DOI: 10.1109/TFUZZ.2010.2062522.

[11] Amsar, R. Munadi, and R. Adriman, "Seleksi Beasiswa Untuk Perguruan Tinggi Berdasarkan Pendekatan Keputusan Berkeadilan Dengan Fuzzy Mamdani,” J. Inotera, vol. 2, no. 2, pp. 1-8, 2017.

[12] Fajar Solikin, “Aplikasi Logika Fuzzy dalam Optimisasi Produksi Barang Menggunakan Metode Mamdani dan Metode Sugeno," Yogyakarta, 2011.

[13] M. D. Irawan, "Sistem Pendukung Keputusan Menentukan Matakuliah Pilihan pada Kurikulum Berbasis KKNI Menggunakan Metode Fuzzy Sugeno,” vol. 13, no. 1, pp. 27-35, 2017.

[14] Kusrini, Pengenalan Sistem Informasi. Yogyakarta: Andi, 2007.

[15] H. Iqbal, Pokok-pokok Materi Statistika 2 (Statistik Inferensif), 2nd ed. Jakarta: PT.Bumi Aksara, 2010 .

[16] S. Nurhayati and I. Immanudin, "Penerapan Logika Fuzzy Mamdani untuk Prediksi Pengadaan Peralatan Rumah Tangga Rumah Sakit Application of Fuzzy Mamdani Logic for Procurement Predictions Hospital Household Appliances," vol. 8, no. 28, pp. 81-87, 2019, doi: 10.34010/komputika.v8i2.2254. 